\title{
A. Stanisławska
}

Gdansk University of Technology, Department of Materials Science and Welding Engineering, Narutowicza 11/12, 80-233 Gdańsk, Poland

alicja.stanislawska@op.pl

\section{BIOMATERIALS AND IMPLANTS IN CARDIAC AND VASCULAR SURGERY - REVIEW}

\begin{abstract}
Currently, on prosthesis in cardiac blood vessels and heart valves are used materials of animal or synthetic origin. For animal materials include, among others pericardial sac in which is the heart. Materials such as this (natural) are characterized by a remarkable biocompatibility within the human body, but their main disadvantage is the relatively low durability. In turn, synthetic materials, which include the austenitic chromium-nickelmolybdenum steels, alloys with a shape memory (nickel-titanium), or polymeric materials, such as lactic acid, are characterized by high stability in an environment of bodily fluids, wherein the insufficiently high biocompatibility with the organism human requires from patients using after implantation, anticoagulants which prevent anti-platelet deposition on the surface of the prosthesis. The present work is a review of biomaterials using in implantology and implants using in cardiac and vascular surgery.
\end{abstract}

Key words: implants, biomaterials, cardiac surgery

\section{INTRODUCTION}

For years, there is performed study about the properties of materials that could be successfully implanted into the human body. These studies show that these materials are a specific group of materials that are characterized by different material composition, chemical structure and mechanical, chemical and biological properties. The major feature of all biomaterials is their biocompatibility [1], which meaning harmony interactions within living matter. Optimum biocompatibility of the biomaterial does not cause acute or chronic inflammatory reaction or does not interfere, and do not disturb the proper differentiation of surrounding of the amputated tissue [2].

A comprehensive definition of a biomaterial was provided at the National Institutes of Health (NIH) Consensus Development Conference on the Clinical Applications of Biomaterials in the United States: A biomaterial is any substance, other than a drug, or combination of substances, synthetic or natural in origin, which can be used for any period of time, as a whole or as a part of a system which treats, augments, or replaces any tissue, organ, or function of the body. This definition was significantly simplified in 1986 at the European Society for Biomaterials Consensus Conference: Biomaterial-a non-viable material used in a medical device intended to interact with biological systems $[3,4]$. 
Biomaterials are one of the most developing trends in the field of materials science. Their use, among others, implants, artificial organs and medical instruments, puts increasing demands on their properties [5].

The main criterias to be taken into account in the selection of biomaterial on implants are: selection of materials for implants and their applications, environmental impact on the behavior of the living body of the implant, the basic assumptions of bioavailability, tissue reaction mechanisms, biophysical, biochemical and biomechanical requirements placed implants, corrosion and abrasion and degradation of a variety of biomaterials, surface layering technology for implants or structural problems. Materials are asked to play more sophisticated, longer-term roles in tissues, customizing and optimizing the material-tissue interface to assure the best longterm clinical outcomes [6]. The cardiovascular system consists of the heart and all the blood vessels. Cardiovascular biomaterials may contact blood (both arterial and venous), vascular endothelial cells, fibroblasts, and myocardium, as well as a number of other cells and acellular matrix material that make up all biological tissue. This chapter will consider a wide range of biomaterials and implants that interact with the heart, blood, and blood vessels.

The main groups of biomaterials used on implants include: bioceramics, polymers, composite materials and metals and their alloys.

\section{BIOCERAMICS}

Ceramics are a material with a group of engineering materials (metals and polymers next). It has properties such as resistance to high temperatures, resistance to chemicals, good mechanical properties, good dielectric properties and thermal, high hardness (wear resistance, fire resistance). Its disadvantages are: low tensile strength and flexural strength, susceptibility to impacts, friability and low resistance to thermal and mechanical shocks. The fragility of the products hinders machining and joining together of ceramic materials or other materials. Porous ceramics exhibit high strength $25-1000 \mathrm{MPa}$, along with the strength of steel, alloys, stone standing. Engineering ceramics are one of the toughest engineering materials after diamond [7].

Ceramics are used in various areas of the economy: construction, metallurgy, electronics, transportation (cars, airplanes) and the space industry. Common are also ceramic fittings home. Ceramics that is used in medicine is called: bioceramics.

The main features of bioceramics may include in particular: porosity - through which it is possible to tissue ingrowths and their lasting connection with implants, good biotolerance and corrosion resistance in the environment of tissues and body fluids [8]. Unfortunately, a major disadvantage of solid ceramic materials such as hydroxyapatite is their limited applicability due to insufficient mechanical properties - primarily poor fracture toughness [9].

Bioceramics have had limited application in cardiovascular devices except for hermetic seals on pacemakers and for insulation in radioablation catheters. Potentially, bioactive ceramics and glasses could have uses for enhanced cell and tissue adhesion. Experimental heart valves have been abricated from ceramics, such as single-crystal sapphire leaflets for heart valves. Ceramic coatings of heart-valve components to improve their wear properties, particularly by chemical vapor deposition methods, e.g., diamond like carbon coatings, are another potential application [10].

Ceramic biomaterials used in medicine can be divided into three groups: resorbable in the body, with controlled surface reactivity, inert [11]. 
The resorbable bioceramics in the body consist of hydroxyapatite (which is also bioactive ceramics) and related calcium phosphates, artificially produced, involved in the metabolism and getting into the tissues. The chemical composition of bioceramic resorbable is similar to the chemical composition of inorganic compounds found in teeth and bones. This type of biomaterial is biologically active and is distinguished by the greatest of all materials biotolerance [12]. Ceramic biomaterials with controlled reactivity in tissues this is primarily bioglass and bioglass-ceramic material. They provide the required biotolerance and the required mechanical properties. Inert ceramic biomaterials exhibit a slight chemical changes upon contact with the tissues and body fluids. Implants made from these materials are a few microns surrounded by fibrous tissue, which is not chemically combined with these materials [13]. Carbons and glassy carbons have been widely used as heart valve components, particularly as pyrolyticcarbon in the leaflets and housings of mechanical valves [14].

Carbon is an important bioceramic. It combines outstanding biocompatibility and chemical inertness. The most important form of carbon for biomedical applications is a type of pyrolytic graphite known as the low temperature isotropic form (LTI carbon).

Low-temperature isotropic carbon is an example of what are referred to as turbostratic carbons. These have a disordered structure based on graphite (and thus are also called turbostratic graphite). In turbostratic carbon the ABABA stacking sequence is disrupted through random rotations or displacement of the layers relative to each other. The individual LTI carbon crystallites are only $<10 \mathrm{~nm}$ in size and are arranged randomly in the bulk material. This microstructure leads to the material having isotropic mechanical and physical properties, unlike graphite in which the properties are highly anisotropic. The density and mechanical properties of LTI are influenced by the number of carbon vacancies in each of the layers and distortions within each plane. The densities range from $1400 \mathrm{~kg} / \mathrm{m}^{3}$ up to a theoretical maximum of $2200 \mathrm{~kg} / \mathrm{m}^{3}$ [15].

High-density LTI carbons are the strongest bulk form of turbostratic carbon; we can increase their strengths further by adding Si. The material then consists of discrete submicrometer ${ }^{\circledR}-\mathrm{SiC}$ particles randomly dispersed in a matrix of roughly spherical micrometer-sized subgrains of pyrolytic carbon; the carbon itself has a "subcrystalline" turbostratic structure, with a crystallite size typically $<10 \mathrm{~nm}$. This is analogous to the microstructure produced during precipitation hardening of metals [16].

One of the major application for LTI carbon is in making prosthetic heart valves. This is one of the most demanding application for biomaterials The first use of LTI carbon in humans for prosthetic heart valve was in 1969. The majority of artificial heart valves currently use Sialloyed LTI pyrolytic carbon [17].

Second well known ceramic is diamond like carbon (DLC). DLC films have found widespread application in biological coatings for implantable medical devices, as a result of their good chemical resistance, temperature stability and biocompatybility. The biological behavior of an important can be tuned by modyfing the element composition. DLC can be easily alloyed with other biocompatible materials such as titanum as well as toxic materials such as silver, cooper and vanadium by normal co-deposition methods [18]. Nanocrystaline diamond-coated medical steel has shown a high level resistance to blood platelet adhesion and thrombi formation [19]. Diamond and DLC coatings have successfully been proposed for cardiac aplications as artificial heart valves, prosthetic stents and surgical scalpels [20-23]. 


\section{POLYMERS}

The polymers are organic materials composed of many identical or different, straight molecules (monomers) connected to macromolecules of high molecular weight. Molecules formed primarily of carbon and hydrogen atoms of the possible participation of oxygen, silicon and sulfur, fluorine and other. Within the molecules formed strong, directional covalent bonds where macromolecules are associated by weak interactions.

Typical properties of this type of materials are: low density, low stiffness, creep resistance, low mechanical strength and thermal conductivity, good insulation properties (electrical and thermal), resistance to weathering and chemicals, ease of shaping.

These are materials that at room temperature are capable of plastic deformation and behave as if their glass transition temperature is lower than room temperature. These include rubbers - natural and artificial, polyurethanes and silicones [24].

Polymeric biomaterials because of medical use can be divided into two groups: natural and artificial [25].

The first of these (natural polymeric biomaterials) are produced in living organisms, as structural components of tissues. They include proteins (collagen, silk, fibrinogen) and polysaccharides (chitin, cellulose, starch). While to artificial biopolymers belong: silicones, polyethylene, polypropylene, polytetrafluoroethylene, polyurethanes, ethylene polyterephthalate, polymethyl methacrylate, and polyamides. To what extent the polymer is suitable for implantation depends on the arrangement and participation auxiliary compounds, such as fillers and plasticizers [26].

Politetrafluoroethylen (PTFE) is widely used in medicine. It is used as vascular prostheses, urological catheters and in cardiac surgery as material for artificial heart valves. Elements PTFE strains are used to bypass the stenosed peripheral arteries and also as a blood substitute. PTFE is highly digestible thermoplastic polymer, that dominating through biocompatibility in contact with the body [27].

PTFE has very good resistance to impact almost chemical substances but also microorganisms and fungi. It is non-toxic, physiologically inert, significantly speeding up the healing process of pierced bodies and does not cause allergic reactions. It can be cut to the appropriate length and threaded. PTFE may also be sterilized $\left(-200^{\circ} \mathrm{C}\right.$ to $\left.260^{\circ} \mathrm{C}\right)$. Due to the fact that the PTFE molecules are characterized by a tendency to repel each other, the material is practically free of any friction (PTFE is less than the friction of ice). It is also resistant to most chemical environments, and the effect of foreign particles [28].

Most fabric vascular prosthesis in current use are constructed from either PET (polyethylene terephthalate) or PTFE fibres. PET and PTFE prostheses are manufactured in two basic constructions; woven or knitted. The woven prosthesis is made up of yarns of filaments running both longitudinally and circumferentially. In order to avoid fraying of the prosthesis at the cut edges the yarns are usually closely packed together, resulting in a tube of relatively low porosity. Knitted prostheses are produced by looping the yarns around the needles. The number and size of needles and the yarn size determine the spacing between the yarns. The yarns in the knitted prosthesis run predominantly in the longitudinal direction. This is known as a warp knit. In prostheses where the yarns run in the circumferential direction, the term used is weft knitting [29,30]. Knitted prostheses are more conformable and are easier to handle and suture than woven prostheses. They are less susceptible to fraying and are therefore better at retaining sutures. However, being more porous, knitted prostheses must be preciotted with the patient's blood prior to implantation [31]. 


\section{COMPOSITE MATERIALS}

Currently used in medicine are: composite materials of carbon-carbon, metal-ceramic, polymer-ceramics and ceramics-ceramics composites.

The carbon-carbon composites are a group of carbonaceous materials characterized by increased strength and fracture toughness. They are also more resistant to thermal shock, as compared with conventional graphite materials and have improved mechanical properties at elevated temperatures [32,33].

In addition purely carbon composite biomaterials also are used composite biomaterials with polymer matrix reinforced with carbon fiber [11].

These materials can be used to perform e.g., carbon composites screws used for connection bone [34]. Because of its good mechanical properties they are also used in cardiac surgery as artificial heart valve [11].

Composites metal - ceramic allow for implants production about high biofunctional characteristics. This combination increases mainly the toughness of the material with respect to the ceramic material. This is due to the addition of a plastic metal [9].

\section{METALS AND ALLOYS}

Metals and their alloys are used in medicine for many years. Nowadays, the materials used for biomedical applications are mainly metallic materials such as 316L stainless steel, cobalt chromium alloys (CoCrMo), titanium-based alloys (Ti-6Al-4V) and miscellaneous others [35]. They have favorable mechanical properties of the band, such as fracture toughness, bending and tensile strength or high resistance to fatigue corrosion. In contrast, their main drawback may be insufficient in some cases, biotolerance and corrosion resistance [36].

The most common steel used for implants is corrosion resistant austenitic stainless steel. It belongs to the group of materials most susceptible to destruction caused by corrosion process. This is due to a very low resistance to corrosion in the electrochemical environment of the body fluids, and a relatively low tendency to naturally self-passivate. Unfortunately implants made of austenitic steel, which are subject to heavy loads can damage more quickly because of the simultaneous effects of corrosive environment and tensile and compressive stresses. Austenitic stainless steels undergo to slower process of destruction while they are subject to smaller load [37].

Austenitic chromium-nickel-molybdenum steels are used, among others, in traumatology, orthopedics, cardiac surgery and maxillofacial surgery [36].

One of the most known stainless steel is also $316 \mathrm{~L}$. Composition of this steel is: $16 \% \mathrm{Cr}$, $2 \%$ Mo and $10 \%$ Ni. $316 \mathrm{~L}$ austenitic stainless steel is nowadays a widely used engineering material due to its excellent corrosion and oxidation resistance and good formability. However, application of this material is hindered by its low mechanical strength and poor anti-friction properties. Strengthening the stainless steel has drawn much attention in the past decades and various approaches have been developed, such as varying its chemical compositions to induce solid solution hardening [38,39] and grain refinement [40-42].

Development of a cobalt matrix alloys was caused by insufficient in some cases bioinerty (the ability to replying substances and products of the reaction occurring inside the body) and the corrosion resistance of steels used for short-term implants, i.e. the period of residence in the tissue environment would not exceed two years. Alloys of cobalt, for example, unlike 
austenitic chromium-nickel-molybdenum, have a much higher resistance to corrosion in the electrochemical environment of body fluids, so can therefore be used for the so-called: longterm implants which can be in the body up to 15 or even 25 years [36].

Titanium and its alloys are characterized by their very high biotolerance, which is associated with high corrosion resistance, good pitting corrosion resistance and ability to repassivation surface damage in a humid and containing oxygen environment. In addition they have favorable mechanical properties simultaneously having almost twice lower specific gravity than steel. In addition, titanium and its alloys are characterized by their ability to osseointegration, which facilitates bone ingrowths. Among all titanium and its alloys, the mainly used materials in biomedicalfield are the commercially pure titanium and Ti-6Al-4V alloy. They are widely used as hard tissue replacements in artificial bones, joints and dental implants. As a hard tissue replacement, the low elastic modulus of titanium and its alloys is generally viewed as a biomechanical advantage because the smaller elastic modulus can result in smaller stress shielding [43]. Other property that makes titanium and its alloys the most promising biomaterials for implants is that titanium-based materials in general rely on the formation of an extremely thin, adherent, protective titanium oxide film. The presence of this oxide film that forms spontaneously in the passivation or repassivation process is a major criterion for the excellent biocompatibility and corrosion resistance of titanium and its alloys [44]. All these features make titanium and its alloys can be widely used biomaterials whose residence time in the body may exceed 25 years [45]. Titanium alloy is mainly used for joint prosthesis, screws, or mechanical heart valves [1].

Gold has also been used as an implant material, but with limited applications. Although gold is resistant to corrosion, its lack of strength and high cost has generally made it a suboptimal choice as an implant [46].

Biomaterials using in medicine and their characterization are shown in Table 1.

Table 1. Characterization of biomaterials using in medicine

\begin{tabular}{|c|c|c|c|c|}
\hline & bioceramics & polymers & composites & metals and alloys \\
\hline types & $\begin{array}{l}\text { - resorbable } \\
\text { - with controlled } \\
\text { reactivity } \\
\text { - indifferent }\end{array}$ & $\begin{array}{l}\text { - natural (collagen, } \\
\text { silk, cellulose) } \\
\text { - artificial (silicones, } \\
\text { polyethylene, } \\
\text { polyamides) }\end{array}$ & $\begin{array}{l}\text { - carbon-carbon } \\
\text { - metal-ceramic } \\
\text {-polymer-ceramics } \\
\text {-ceramics-ceramics } \\
\text {-polymer-polymer }\end{array}$ & $\begin{array}{c}\text { - steel } \\
\text { - cobalt alloys } \\
\text { - titanium and its } \\
\text { alloys } \\
\text {-noble metals and } \\
\text { their alloys } \\
\text {-shape memory alloys }\end{array}$ \\
\hline disadvantages & brittle & $\begin{array}{l}\text { low resistance to high } \\
\text { temperatures and } \\
\text { lower mechanical } \\
\text { properties (hardness, } \\
\text { creep susceptibility) } \\
\text { compared to metal or } \\
\text { ceramic }\end{array}$ & $\begin{array}{l}\text { sometimes } \\
\text { insufficient } \\
\text { biotolerance }\end{array}$ & $\begin{array}{c}\text { insufficient } \\
\text { biotolerance and } \\
\text { corrosion resistance }\end{array}$ \\
\hline advantages & hard & $\begin{array}{c}\text { low density, } \\
\text { corrosion resistance, } \\
\text { ease of processing }\end{array}$ & $\begin{array}{l}\text { strength, fracture } \\
\text { toughness and } \\
\text { thermal shock }\end{array}$ & $\begin{array}{l}\text { resistance, fracture } \\
\text { toughness, flexural } \\
\text { and tensile strength }\end{array}$ \\
\hline application & $\begin{array}{l}\text { dental implants, } \\
\text { parts of } \\
\text { endoprothesis, } \\
\text { artificial heart } \\
\text { valves }\end{array}$ & $\begin{array}{l}\text { artificial ligaments, } \\
\text { joints and acetabular } \\
\text { prostheses in } \\
\text { dentistry }\end{array}$ & $\begin{array}{l}\text { dental elements, } \\
\text { artificial heart } \\
\text { valves, artificial } \\
\text { ligaments }\end{array}$ & $\begin{array}{l}\text { dental prostheses, } \\
\text { mechanical heart } \\
\text { valves }\end{array}$ \\
\hline
\end{tabular}




\section{IMPLANTS USED IN CARDIO-VASCULAR SURGERY}

\section{Stents}

In the case of stenosis of blood vessels to improve blood flow may be used cardiovascular stents. These are the coils implanted to the narrowed artery during angioplasty process, which are introduced in order to increase the light of the blood vessels. Stands out self-expanding stents made of shape memory alloys such as Nitinol and the stents placed in the catheter with a balloon made of a special 316L stainless steel. Because of their functions, stents can be structurally divided into 4 groups: mesh stents, tubular in shape, ganglion-shaped stents and the annular coil (Fig. 1). The most important feature of all stents is no formation of thrombus upon contact with the surface of the material because clot formation at the implantation site of the implant may lead to occlusion of the artery. If the material from which the stent is made does not have this property, the stent is covered by special coatings such as calcium phosphate or carbon, which prevent the formation of blood clots. For other requirements belong: resistant to changing blood pressure, the small diameter of the stent, the flexibility, the lack of cross-section changes in tension, high fatigue strength, maintaining a patent, biocompatibility, resistance to infection, availability, and ease of implantation $[47,48]$.

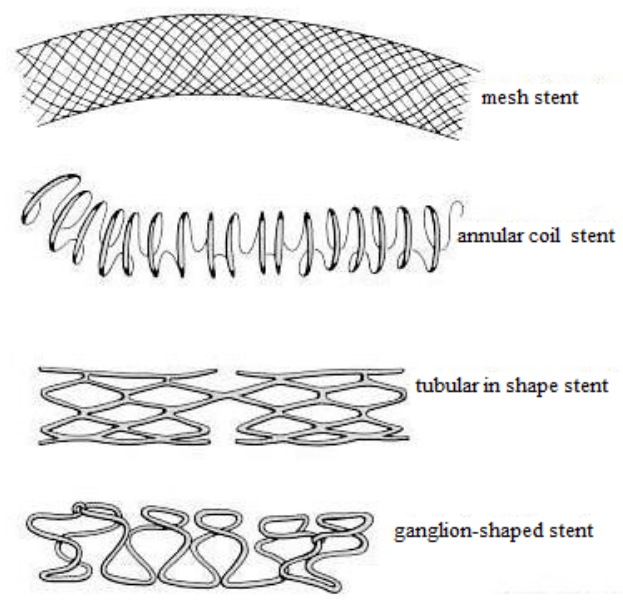

Fig. 1. Types of stents [49]

\section{Artificial Heart Valves}

Cardiac valve prostheses due to the type of material from which they are made can be divided into two groups: mechanical and biological valves.

\section{Mechanical heart valves}

Mechanical heart valve prostheses are made from synthetic materials like metals and their alloys or synthetic polymers. An essential feature of the structural difference between the mechanical valves is their mechanism of opening and closing. All designs are based on the principle of differential pressures during the heart cycle. In creation of the mechanical artificial heart valves can distinguish two types of blood flow: central occurring in disk valves and microbe and transverse occurring in ball valves. In terms of construction mechanical valve can be divided into three groups: cage shape (elastic), ball shape (Fig. 2.), disk shape (Fig. 3.) and double petal [50]. Unfortunately, mechanical heart valves because of their 
insufficient biocompatibility cause hemolysis of blood, leading to its coagulation, and consequently require by patients anticoagulation treatment. Despite this, the mechanical valves are often used in cardiac surgery, due to its stability, which reduces the risk of reoperation due to valvular dysfunction.
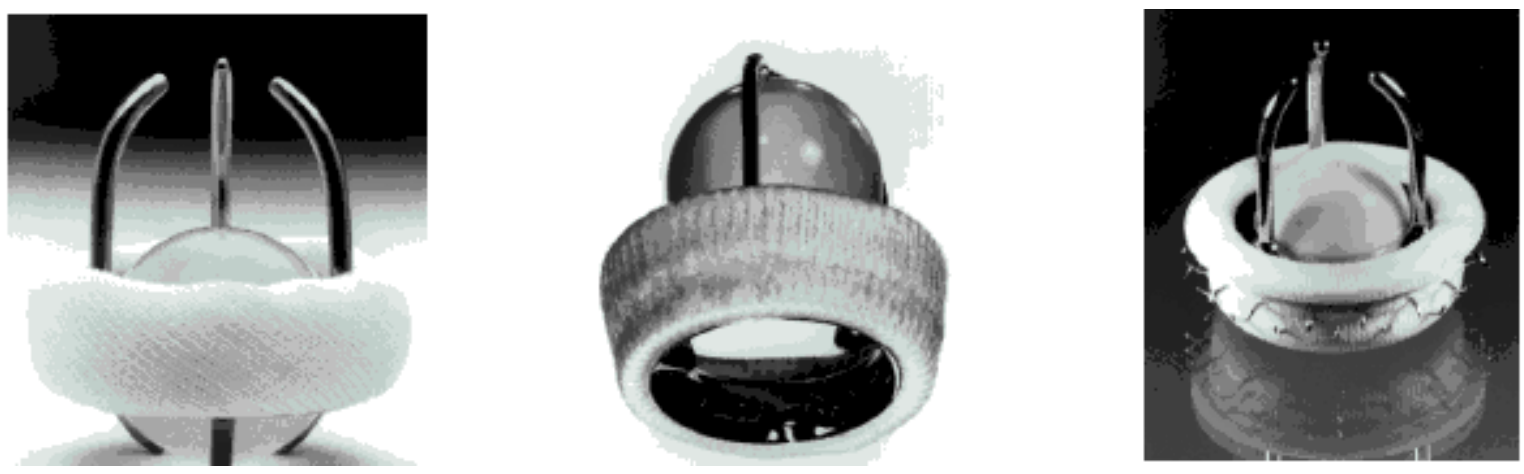

Fig. 2. Mechanical heart valve with ball shape [51]
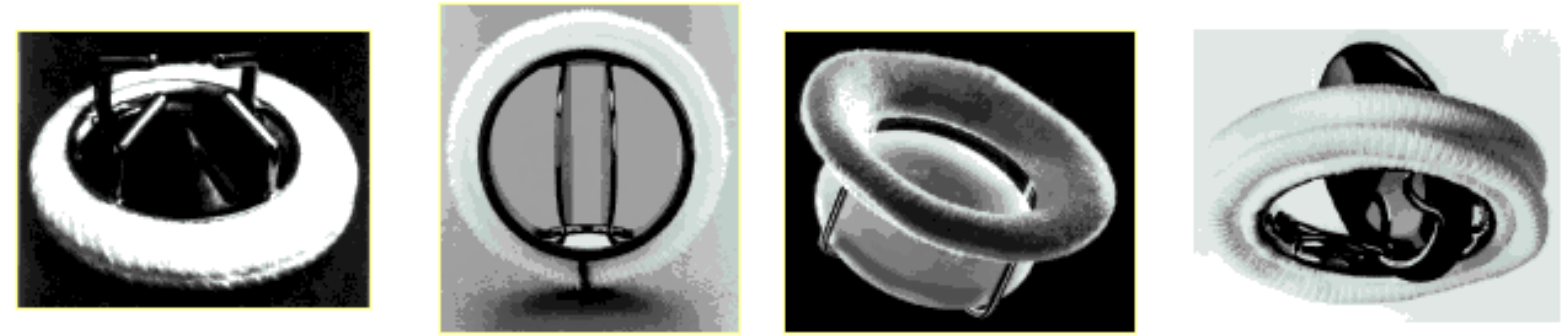

Fig. 3. Mechanical heart valve with disc shape [51]

Each mechanical heart valve consists of three basic components [52], which are: the locking element - usually one or more moving parts in the form of a ball, a single disk or circular or semi-circular set of petals; cover - the so-called cage, wherein the locking element moves or ring made of graphite or metal for which it is attached by means of a locking element wires (disk or flakes) and base - typically in the form of a ring edged with synthetic fabric.

The ball valves used for the first case made of acrylic and silicone rubber ball. Early mitral Starr-Edwards (SE) consisted of a basket formed by the arms positioned around the ring of stainless steel and silicone balls. Thereafter, the material from which made cart, replaced cobalt alloy (61-63\%), chromium (25.5-29\%), molybdenum (5-6\%) and nickel (1.75-3.75\%). The composite silicone modified by doping bar sulfate, applicability to imaging. An annulus made of silicone rubber coated with a composite of polytetrafluoroethylene (PTFE) and polypropylene material [53]. Since 1960, the year in which it was created the first valve SE, and several models with different structures, of which today is used only one - SE 1260 [50].

The first valve disk Bjork-Shiley consisted of a basket made of a material Stellite-21(CoCr-Mo alloy) polyacetylene disc (Delrin) and the politetrafluoroetylene retaining ring (PTFE). Both the Derlin and PTFE tested for use in the production of discs and proved that Teflon is much faster than Delrin consumption [54]. However, the Delrin also has some disadvantages. Absorbs water vapor during the sterilization process and undergoes deformation, which may cause malfunctioning of the valve. Such damage contributed to the development of new material - pyrolytic carbon (LTI called carbon), which performed the valve elements in later 
generations Bjork-Shiley valves. This material has a role to today's most preferred biomaterial used in cardiac valves, as it is characterized by excellent biocompatibility, and longevity in the environment of the body fluids [53].

History of double disc valves was launched in 1977 by the introduction of today's most popular design - the St. Jude Medical valve [55]. In these valves, two cereals, entirely made of carbide, are mounted in special cylindrical hinge arranged blood flow side. Opening the inside they produce three holes: two large laterals and one central [49].

The next constructions were CarboMedics and Bicarbon-Sorin valves. Structures of various double disc valves differed from each other opening angles, the nature of the surface of the disk (flat - St. Jude, CarboMedics or cylindrical - Bicarbon-Sorin, Duromedics) and carbon surface preparation technology. CarboMedics valve entirely made from titanium with carbon coating. Valve orifices are equipped with two semicircular jumpers (cross connectors flakes) placed in the ring on hinges. The large diameter allows achieving a flat, almost normal blood flow, as compared with the older generation valves. However, the data on the occurrence of thromboembolic show that this type of valve is not perfect, and as with other mechanical valves it is necessary to long-term anticoagulant therapy [56]. Currently, in addition to traditional anticoagulation medicines such as Acenokumarol or Wargin, newer agents are used to ensure safety in clinical situations such as safe for women with a pregnancy $[57,58]$.

\section{Biological heart valves}

Depending on the construction of a biological valve (Fig. 4.) are divided into stent and stentless. Stent-valves are also called valvular bioprothesis because they combine the features of artificial prosthesis (presence of a stent or frame), with biological material of different origin [50].

The first biological valve from the people - homografts was introduced in 1962, although the limited availability limited the use thereof. In 1965, J. Binet and A. Carpentier for the first time used the material zoonotic - heterograft, but its durability has proven to be limited [50]. The fundamental breakthrough in the design and accessibility of biological valves was used in 1968 by A. Carpentier new method of fixation of biological material by using glutaraldehyde. This led to the mechanical reinforcement by the binding of collagen present in the tissue, loss of susceptibility to proteolytic enzymes and a significant reduction in the antigenic properties. Those valves came to be called bioprothesis, because they merged the idea of biological and artificial valve. In 1970 appeared the first pig valve mounted on the stent - Hancock, in 1971 a second similar - Carpentier-Edwards. In the same year, the first valve made of pericardium Ionescu, and in 1980, pericardial valve Carpentier-Edwards [50]. The fundamental weakness of all biological valves is their limited durability, leading to loss their function. It depends on many factors, primarily on the age of the patient and place where the valve is implanted. Currently used biological valve present a 15-year absence of structural defects, amounting $88 \%$ in the aortic position and $66 \%$ in the mitral position [59].

Thanks to new technologies, preservation of biological material and the ongoing research concerning the construction, operation and characteristics of blood flow through the aortic valve in the heart, manages to obtain biological valves for increased durability and increasingly sophisticated hemodynamic characteristics which allows a continuous increase in competitiveness compared to mechanical valves. 


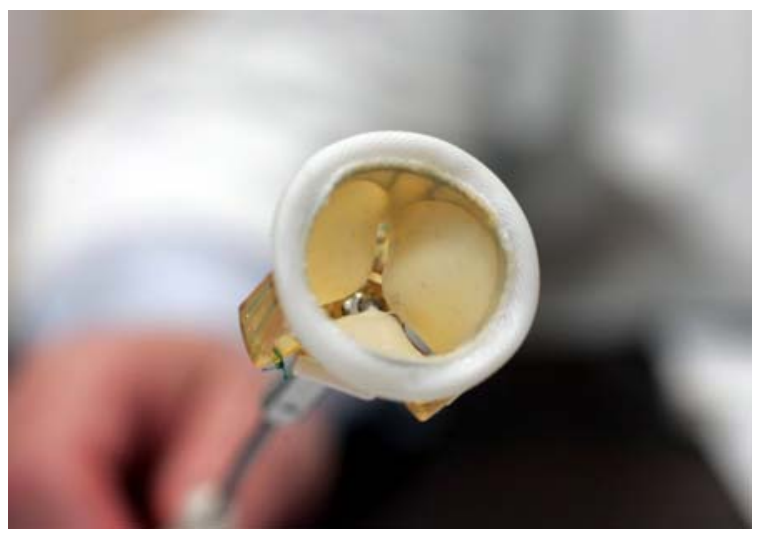

Fig. 4. Biological heart valve of new generation [60]

\section{FORECASTING FUTURE}

Development of medicine significantly associated with the progression of chemical sciences and materials science. Progress in these disciplines cause the desire to search for new materials that could be successfully implanted into the human body. These new materials are called smart materials can provide synergy to the system of man and is not exposing it to unwanted side effects. In the near future is likely to find use herein conducting polymers, materials produced by means of nanotechnology or composite materials with controlled properties. There are looking for a hybrid, synthetic-biology and materials with special properties. Increasingly, also biological structures arise in vitro, which contributes to the development of tissue engineering and genetic.

\section{REFERENCES}

1. Świeczko-Żurek B., Zieliński A., Sobieszczyk S., Ossowska A.: Biomaterials [in Polish], Gdansk Univ. of Technology, 2011.

2. Poloński L. [ed.]: Fundamentals of cardiology [in Polish]. Katowice, Śląska Akademia Medyczna, 2000.

3. Williams D.F.: Definitions in biomaterials. Amsterdam - Oxford - New York Tokyo, Elsevier (1987), 24.

4. Williams D.F.: Definitions in biomaterials. Progress in Biomedical Engineering 4 (1987), 67.

5. www.imz.us.edu.pl, date of download: 12.10.2013.

6. Bergmann C.P., Stumpf A.: Dental ceramics, Topics in mining. Metallurgy and materials engineering, 2 Springer-Verlag Berlin Heidelberg, 2013.

7. Kucharczyk W., Mazurkiewicz A., Żurowski W.: Modern construction materials - selected issues [in Polish]. Politechnika Radomska, Radom, 2008.

8. Blicharski M.: Introduction to engineering materials [in Polish]. WNT Warszawa, 2003.

9. Dudek A., Przerada I.: Metallic-ceramic composites for use in medicine [in Polish]. Materiały ceramiczne, 62, 1 (2010), 20-23. 
10. Snyder R.W., Helmus M.N.: Cardiovascular biomaterial, standard handbook of biomedical engineering and design, 2004.

11. Nowacki J., Dobrzański L.A., Gustavo F: Intramedullary implants in long bones osteosynthesis, Gopen Access Library, 11, 2012.

12. Schliephake H., Kage T.: Enhancement of bone regeneration using resorbable ceramics and a polymer-ceramic composite material. Journal of biomedical materials research, 56 (2001), 1.

13. Hench L.L., Paschall H.A.: Direct chemical bond of bioactive glass-ceramic materials to bone and muscle. Journal of biomedical materials research, 7, 3 (1973), 25-42.

14. Ritchie R.O.: Fatigue and fracture of pyrolytic carbon: A damage-tolerant approach to structural integrity and life prediction in 'ceramic' heart valve prostheses. Journal of heart valve disease, 5, 1 (1996) 9-31.

15. Robert A., Freitas J.: Pyrolytic or low temperature isotropic carbon, Nanomedicine IIA: Biocompatibility, Landes Bioscience, Georgetown, TX, 2003.

16. Davis J.R.: Handbook of materials for medical devices, 6, 2003, 148.

17. Carter C.B., Norton M.G.: Ceramic materials: science and engineering, 35, 635-651.

18. Scheerded I.D.: The Biocompatibility of diamond-like carbon nano films, J. Invasive Cardiology 12, 2000, 389-394.

19. Okroj W., Kamińska M., Klimek L., Szymański W., Walkowiak B.: Blood platelets in contact with nanocrystalline diamond surfaces, Diamond\&related materials 15, 10 (2006), 1535-1539.

20. Grill A.: Diamond-like carbon coatings as biocomplatible materials- an overview. Diamond\&related materials, 12, 2 (2003), 166-170.

21. Hauert R.: A review of modified DLC coatings for biological applications. Diamond\&related materials 12, 3-7 (2003), 583-589.

22. Freitas R.A.: Foresight Update, 39 Foresight Inst. Palo-Alto, CA, USA, 1999.

23. Dearnley P.A.: A review of metalli, ceramic and surface treated metals used for bearing surface in human joint replacements. Proc. of institution of mechanical engineers. Art H., Engineering in medicine, 213 (1999), 107-135.

24. Brinson H.F, Brinson L.C., Polymer engineering science and viscoelasticity: characteristics, applications and properties of polymers, 2008, 55-97.

25. Świeczko - Żurek B: Biomaterials [in Polish], Wydawnictwo Politechniki Gdańskiej, 2009, Gdańsk

26. Sowa-Lewandowska K.: Real or artificial? - A few words about the biomaterials. www.laboratoria.net.pl, date of download: 16.10.2013

27. Guidoin R.C., Snyder, R.W., Awad J.A., King, M.W.: Biostability of vascular prostheses. Cardiovascular biomaterials, Hastings, GW [ed.]. New York: Springer-Verlag, 1991.

28. www.ptfe.net.pl, date of download 4.01.2014.

29. Maarek J.M., Guidoin R., Auhin M., Prud'homme R.E.: Molecular weight characterisation of virgin and explanted polyester arterial prostheses. Journal biomedical materials research 18 (1984), 881-894.

30. Guidoin R., Martin L., Marois M, Gosselin C., King M., Gunasekera K., Domurado D., SigotLuizard M.F., Sigot M., Blais P.: Polyester prostheses as suhstitutes in the thoracic aorta of dogs. II. Evaluation of alhuminated polyester grafts stored in ethanol. Journal biomedical material research 18 (1984), 1059-1072. 
31. Cengiz M., Sauvage L.R., Berger K, Rohel S.B., Robel V., Wu H.D., Walker M., Appleyard R.F., Wood S.J.: Effects of compliance alteration on healing of a porous Dacron prosthesis in the thoracic aorta of the dog. Surgical gynecological obstet 158 (1984), 145-151.

32. Błażewicz M., Błażewicz S., Chłopek J., Staszków E.: Structure and properties of carbon materials for medical applications. Ceramics in substitutive and reconstructive surgery. Amsterdam: Elsevier, 1991.

33. Błażewicz M.: Carbon materials in the treatment of soft and hard tissue injuries. European cells and materials 2 (2001), 21-29.

34. Nałęcz M. [ed.]: Biocybernetics and biomedical engineering 2000, Vol. 4 Biomaterials [in Polish]. PAN, Akademicka oficyna wydawnicza Exit, 2003.

35. Liu X., Chu P.K., Ding C.: Surface modification of titanium, titanium alloys, and related materials for biomedical applications. Material science engineering 47 (2004), 49-121.

36. Marciniak J.: Biomaterials [in Polish]. Wydawnictwo Politechniki Śląskiej, 2002, Gliwice.

37. Talonen J., Nenonen P., Pape G., Hänninen H.: Effect of strain rate on the strain-induced martensite transformation and mechanical properties of austenitic stainless steels, Metallurgical and materials transactions A, 432, 36A, February 2005.

38. Pelletier H., Muller D., Mille P., Cornet A., Grob J.J.: Surf. Coat Technol. 2002, 151-377.

39. Rawers J., Crogdon F., Krabbe R., Duttlinger N., Powder Metall., 39, 1996.

40. Fujiwara H., Ameyama K.: Mater Sci. Forum, 47 (1999), 304-306.

41. Ucok I., Ando T., Grant N.J.: Mater Sci. Eng. A, 1991, 133:284.

42. Pakiela Z., Sus-Ryszkowska M., Druzycka-Wiencek A., Kurzydlowski K.J..: Seventh Int. Conf. on Nanostructured Materials, Germany, 20-24 June 2004.

43. Elias C.N., Lima J.H.C., Valiev R., Meyers M.A.: Biomedical applications of titanium and its alloys, Biological materials science, 2008 March JOM, 46-49.

44. de Viteri V.S., Fuentes E., Titanium and titanium alloys as biomaterials, Tribology fundamentals and advancements, 2013 May, 155-174.

45. Krasicka-Cydzik E., Mstowski J., Ciupik L.F.: Implant materials: steel and titanium alloys, Dero system: The development of operational techniques of treatment of spine.

46. Breitbart A.S., Ablaza V.J., Implant materials, Grabb and Smith's Plastic Surgery, Sixth Edition by Charles H. Thorne, Copyright (C) 2007 by Lippincott Williams \& Wilkins.

47. Stodolak E., Frączek-Szczypta A., Mikociak D., Morawska-Chochół A., Szaraniec E., Zima A.: Laboratory of subject: implants and artificial organs [in Polish], Międzywydziałowa Szkoła Inżynierii Biomedycznej, AGH, Kraków, 2009.

48. Kaczmarek M., Tyrlik-Held J., Paszenda Z., Marciniak J.: Characteristics of stents in terms of application and material.. Achievements in mechanical\&materials engineering. 12th international scientific conference, Politechnika Śląska, Gliwice (2003), 421-428.

49. Gąsior Z., Stępińska J.: Advances in the diagnosis and treatment of acquired valvular heart defects [in Polish], Centrum Medyczne Kształcenia Podyplomowego w Warszawie (2011).

50. http://rcpals.com/downloads/2007files/may/accaha/type_of_stents.html, date of download: 2.01.2014

51. Kopernik M: The role of supporting research in the design of artificial ventricle, 2008.

52. Butany J., Ahluvalia M.S., Munroe C., Fayet C., Ahn C, Blit P, Kepron C, Cusimano R.J., Leask R.L.: Mechanical heart valve prosthesis: identification and evaluation (erratum). Cardiovascular pathology, 12 (2003), 322-344. 
53. Rachwalik M., Biały D., Wawrzyńska M.: Mechanical prosthetic heart valves - the history and development of technology. Acta Bio-optica et. Informatica Medica, 2012.

54. Bhuvaneshwar G.S., Muraleedharan C.V., Ramani A.V., Valiathan M.S.: Evaluation of materials for artificial heart valves. Bull. Material Science, 14 (1991), 1361-1374.

55. Bloomfield P.: Choice of heart valve prosthesis, Heart, BMJ Group, http://www.ncbi.nlm.nih.gov/pmc/articles/PMC1767148/

56. Muraleedharan C.V., Bhuvaneshwar G.S.: Failure mode and effect analysis of Chitra heart valve prosthesis, Proc. RC IEEE \& 14th BMESI, New Delhi, 1995, 352-354.

57. Corbett T.L., Elher K.S., Garwood C.L.: Successful use of fondaparinux in a patient with a mechanical heart valve replacement and a history of heparin-induced thrombocytopenia, $\mathrm{J}$ Thromb thrombolysis 1 (2010), 23.

58. Quinn J., Von Klemperer K., Brooks R.: Use of high intensity adjusted dose low molecular weight heparin in women with mechanical heart valves during pregnancy: a single-center experience, Haematologica 9 (2009), 1608-1612.

59. Khan S., Trento A., DeRobertis M.: Twenty-year comparison of tissue and mechanical valve replacement, The journal of thoracic and cardiovascular surgery 122 (2001), 257-268.

60. www.cskmswia.pl, Department of Cardiac Surgery - Poland's first operation of biological heart valve implantation of the latest generation, date of download: 31.01.2014. 